\title{
PENERAPAN MODEL PEMBELAJARAN KOOPERATIF TIPE NHT SEBAGAI UPAYA DALAM MENINGKATKAN AKTIVITAS DAN PRESTASI BELAJAR SISWA DALAM PEMBELAJARAN INTEGRAL TAK TENTU
}

\author{
I Made Dharma Atmaja \\ Program Studi Pendidikan Matematika Fakultas Keguruan dan Ilmu Pendidikan \\ Universitas Mahasaraswati Denpasar \\ dharma.atmaja07@gmail.com
}

\begin{abstract}
ABSTRAK
Berdasarkan hasil observasi di kelas XI SMK Saraswati 2 Denpasar, ditemukan beberapa kendala saat pembelajaran berlangsung, diantaranya (1) keterlibatan siswa dalam mengikuti pembelajaran masih sangat kurang, (2) siswa kurang siap dalam mengikuti pembelajaran, (3) kurangnya kerjasama antara siswa dalam menyelesaikan tugas, (4) siswa belum dapat menyimpulkan materi yang dipelajari. Sesuai dengan data yang diambil melalui wawancara terhadap guru matematika kelas XI SMK Saraswati 2 Denpasar diperoleh prestasi pembelajaran matematika dikategorikan rendah, karena belum mencapai kriteria ketuntasan minimum yang telah ditetapkan di SMK Saraswati 2 Denpasar. Penelitian ini menggunakan pendekatan kualitatif dan jenis penelitian ini adalah penelian tindakan kelas (PTK). Penelitian ini dilaksanakan sampai dua siklus. Presentase peningkatan skor rata-rata aktivitas belajar siswa dari siklus I ke siklus II sebesar $43,31 \%$ dan persentase peningkatan rata-rata nilai prestasi belajar siswa, ketuntasan belajar, dan daya serap dari siklus I ke siklus II berturut-turut sebesar: 8,31\%;31,99\%; dan 8,31\%. Berdasarkan hasil penelitian ini, maka dapat disimpulkan bahwa aktivitas dan prestasi belajar siswa dalam pembelajaran integral tak tentu fungsi aljabar melalui penerapan model pembelajaran kooperatif tipe NHT pada siswa kelas XI SMK Saraswati 2 Denpasar tahun pelajaran 2014/2015 mengalami peningkatan.
\end{abstract}

Kata Kunci: Penerapan, Model Pembelajaran Kooperatif Tipe NHT, Aktivitas Belajar, dan Prestasi Belajar

\begin{abstract}
Based on observations in class XI of Saraswati 2 Denpasar Vocational High School, several obstacles were found when learning took place, including (1) student involvement in learning was still lacking, (2) students were less prepared to take part in learning, (3) lack of collaboration between students in completing assignment, (4) students have not been able to conclude the material being studied. In accordance with the file taken through interviews with the mathematics teacher of class XI of Saraswati 2 Denpasar Vocational High School, information the achievement of mathematics learning is categorized as low, because it has not reached the minimum completeness criteria that have been established of Saraswati 2 Denpasar Vocational High School. This study uses a qualitative approach and this type of research is a classroom action study (CAR). This research was carried out for up to two cycles. The percentage increase in the average score of student learning activities from cycle I to cycle II is $43.31 \%$ and the percentage increase in the average value of student learning achievement, learning completeness, and absorption from cycle I to cycle II are respectively: 8, 31\%; $31.99 \%$; and $8.31 \%$. Based on the results of this study, it can be concluded that the activities and student achievement in integral learning are not necessarily algebraic functions through the application of NHT type cooperative learning model in class XI students of Saraswati 2 Denpasar Vocational High School 2014/2015 of the academic year has increased.
\end{abstract}

Key Words: Application, NHT Type Cooperative Learning Model, Learning Activity, and Learning Achievement 


\section{PENDAHULUAN}

Pentingnya pendidikan bukan suatu hal yang diragukan lagi di seluruh dunia khususnya di Indonesia, karena kemajuan suatu negara terletak pada kemajuan pendidikan masyarakat. Sesuai dengan salah satu tujuan negara yang tercantum dalam Undang-Undang Dasar 1945 yaitu mencerdaskan kehidupan bangsa maka setiap warga negara Indonesia wajib mengikuti pendidikan dalam mengembangkan bakat dan kemampuannya. Pendidikan merupakan kebutuhan yang sangat penting dan berlangsung sepanjang masa. Pendidikan dapat membantu manusia dalam mengembangkan diri, sehingga mampu menghadapi perubahan yang terjadi dalam kehidupannya. Pendidikan yang baik akan menghasilkan sumber daya manusia yang berkualitas baik bagi diri sendiri, bangsa, dan negara sehingga mampu bersaing dan berkompetisi dengan negara lain. Dengan demikian, pendidikan harus betul-betul diarahkan untuk menghasilkan manusia yang berkualitas, mampu bersaing, memiliki budi pekerti luhur dan moral yang baik.

Pendidikan memiliki kaitan yang sangat erat dengan sekolah sebagai tempat untuk memperoleh pendidikan secara formal.

Keberhasilan pendidikan dapat tercapai apabila seluruh komponen pendidikan, antara lain: guru, siswa, model pembelajaran, sarana prasarana belajar dan lingkungan dapat berjalan secara berkeseimbangan. Guru dan model pembelajaran merupakan dua komponen penting yang menentukan aktivitas dan prestasi belajar. Guru hendaknya mampu menggunakan model pembelajaran yang bervariasi untuk meningkatkan kualitas pembelajaran di kelas pada semua mata pelajaran. Salah satunya adalah pelajaran matematika. Matematika sebagai ilmu dasar memegang peranan yang sangat penting dalam pengembangan sains dan teknologi, karena matematika merupakan cara berpikir untuk mengembangkan cara berpikir logis, sistematis, dan kritis. Aplikasi bidang matematika juga dapat diterapkan pada bidang lainnya sehingga tidak berlebihan jika dikatakan bahwa matematika adalah ilmu dasar. Namun pada saat sekarang ini matematika merupakan salah satu bidang ilmu yang kerap ditakuti peserta didik. Hal tersebut harus dihilangkan karena sebagai ilmu dasar dan ilmu bantu bagi bidang ilmu lain, 
matematika memiliki peranan yang sangat penting.

Berdasarkan hal tersebut maka dilakukan pengamatan terhadap siswa dan guru pada kelas XI SMK Saraswati 2 Denpasar. Hasil pengamatan menunjukkan bahwa (1) dalam mengikuti pelajaran masih ada siswa yang tampak keterlibatannya sangat kurang, (2) siswa kurang siap dalam mengikuti pembelajaran. Hal ini terlihat pada saat guru memberikan pertanyaan, beberapa siswa tidak bisa menjawab pertanyaan tersebut. (3) kurangnya kerjasama antar siswa dalam menyelesaikan tugas yang diberikan oleh guru selama proses pembelajaran berlangsung, (4) siswa belum dapat menyimpulkan materi yang telah dipelajari.

Sesuai dengan data yang diambil melalui wawancara terhadap guru mata pelajaran matematika kelas XI di SMK Saraswati 2 Denpasar diperoleh informasi nilai rata-rata prestasi siswa, ketuntasan belajar, dan daya serap dari hasil ulangan semester Ganjil, yaitu berturut-turut adalah 65,$85 ; 14,63 \%$; dan $65,85 \%$. Hal ini menunjukkan prestasi pembelajaran matematika dikategorikan rendah karena belum mencapai Kriteria
Ketuntasan Minimum (KKM) yang telah ditetapkan yaitu nilai rata-rata, ketuntasan belajar, dan daya serap berturut-turut minimal mencapai 78 ; $80 \%$; dan $78 \%$.

Berdasarkan uraian di atas, timbul ketertarikan untuk mengadakan suatu penelitian dengan judul "Penerapan Model Pembelajaran Tipe NHT Sebagai Upaya Meningkatkan Aktivitas Dan Prestasi Belajar Siswa Dalam Pembelajaran Integral Tak Tentu Fungsi Aljabar Pada Siswa Kelas XI SMK Saraswati 2 Denpasar Tahun Pelajaran 2014 / 2015.”

\section{METODE PENELITIAN}

\section{Pendekatan dan Jenis Penelitian}

Penelitian ini menggunakan pendekatan kualitatif yang sering disebut penelitian naturalistik karena salah satu ciri penelitian ini mempunyai latar alami (natural setting). Menurut Patton (dalam Wirawan, 2011:155) dalam penelitian kualitatif peneliti tidak berupaya untuk memanipulasi latar penelitian, unobtrusive, tidak mengontrol, terbuka terhadap apa yang terjadi atau muncul dan tidak ditentukan sebelumnya.

Jenis penelitian yang dilakukan adalah Penelitian Tindakan Kelas 
(PTK). Menurut Eliton (dalam Sanjaya 2009:25) menyatakan penelitian tindakan adalah kajian tentang situasi sosial dengan maksud untuk meningkatkan kualitas tindakan melalui proses diagnosis, perencanaan, pelaksanaan, pemantauan, dan mempelajari pengaruh yang ditimbulkannya.

\section{Desain Penelitian}

Desain penelitian yang digunakan pada penelitian ini berbentuk siklus model Kemmis dan Mc Taggart. Siklus ini tidak hanya berlangsung satu kali, tetapi beberapa kali hingga tercapai tujuan yang diharapakan. Desain penelitian ini adalah perencanaan, struktur dan strategi penelitian dalam rangka mengendalikan penyimpangan yang mungkin terjadi dan menjawab pertanyaan yang mungkin terjadi. Alur penelitian tindakan ini terdiri dari empat langkah yaitu 1) rencana (planing), 2) tindakan (acting), 3) observasi (observing), 4) refleksi (reflection).

Menurut Arikunto (2010: 131) konsep yang dikembangkan dari Kemmis dan Mc Targgat dalam model ini adalah komponen tindakan (acting) dengan pengamatan (observing) disatukan dengan alasan kedua kegiatan tersebut tidak dapat dipisahkan karena kedua kegiatan ini haruslah dilakukan dalam satu kesatuan waktu. Begitu berlangsung suatu kegiatan dilakukan, kegiatan observasi harus dilakukan sesegera mungkin. Hasil pengamatan ini dijadikan dasar untuk langkah refleksi yaitu mencermati apa yang sudah terjadi.

\section{Pengecekan Keabsahan Data}

Untuk mengecek keabsahan data penelitian ini menggunakan teknik triangulasi dan pemeriksaan sejawat dengan guru serta melalui diskusi dengan dosen pembimbing.

\section{Posedur Penelitian}

\section{Refleksi Awal}

Rendahnya prestasi belajar matematika siswa diduga disebabkan oleh rendahnya aktivitas siswa. Rendahnya aktivitas siswa itu sendiri disebabkan karena (1) keterlibatan siswa dalam mengikuti pembelajaran masih sangat kurang, (2) siswa kurang siap dalam mengikuti pembelajaran, (3) kurangnya kerja sama antar siswa dalam menyelesaikan tugas yang diberikan oleh guru, dan (4) siswa belum dapat menyimpulkan materi yang dipelajari. 
Berdasarkan refleksi awal diatas, maka diterapkan model pembelajaran kooperatif tipe NHT karena pembelajaran kooperatif tipe NHT adalah pembelajaran yang lebih menekankan kepada struktur khusus yang dirancang untuk mempengaruhi pola interaksi siswa agar memiliki tujuan untuk meningkatkan penguasaan akademik.

\section{Siklus I}

Siklus I terdiri dari 3 komponen meliputi perencanaan (planning), pelaksanaan tindakan dan pengamatan (action and observing), dan refleksi (reflecting). Pada siklus I dilakukan 3 kali pertemuan dengan rincian 2 kali pertemuan untuk pelaksanaan tindakan dan 1 kali pertemuan untuk tes akhir siklus. Pertemuan pertama membahas tentang konsep integral sebagai kebalikan turunan fungsi. Pertemuan kedua membahas tentang pengertian integral tak tentu fungsi aljabar. Setiap akhir pertemuan siswa diberikan kuis yang dikerjakan secara individu dan diakhir siklus diberikan tes untuk mengukur prestasi belajar siswa. Tes yang digunakan adalah objektif dan uraian.

\section{Siklus II}

Siklus ini dilakukan untuk memperbaiki kekurangan dan kelemahan yang terdapat pada siklus I. tahap-tahap siklus II hampir sama dengan tahap-tahap pada siklus I, dengan perbaikan-perbaikan yang dilakukan berdasarkan hasil refleksi. Seperti pada tabel dibawah ini.

\section{HASIL DAN PEMBAHASAN PENELITIAN}

Berdasarkan analisis data aktivitas belajar siswa maka dapat disajikan hasil analisis data aktivitas belajar siswa seperti pada tabel 01 berikut.

Tabel 01. Rekapitulasi Hasil

Analisis Data Aktivitas Belajar Siswa

\begin{tabular}{|c|c|c|c|}
\hline $\begin{array}{c}\text { Sik } \\
\text { lus }\end{array}$ & $\begin{array}{c}\text { Pertem } \\
\text { uan ke- }\end{array}$ & $(\overline{\mathbf{A}})$ & Kat \\
\hline I & 1 & 8,09 & $\begin{array}{c}\text { Kurang } \\
\text { aktif }\end{array}$ \\
\hline & 2 & 10,78 & $\begin{array}{c}\text { Cukup } \\
\text { Aktif }\end{array}$ \\
\hline & $\begin{array}{c}\text { Rata- } \\
\text { rata }\end{array}$ & 9,43 & $\begin{array}{c}\text { Cukup } \\
\text { Aktif }\end{array}$ \\
\hline II & 4 & 13,7 & Aktif \\
\hline & 5 & 14,46 & Aktif \\
\hline & $\begin{array}{c}\text { Rata- } \\
\text { rata }\end{array}$ & 14,08 & Aktif \\
\hline
\end{tabular}

Keterangan:

$(\overline{\mathrm{A}})$ : Rata-rata skor aktivitas belajar siswa Kat : Kategori

Dari tabel 01 di atas dapat diketahui bahwa terjadi peningkatan dari siklus I ke siklus II yaitu dari 
kategori "cukup aktif" menjadi "aktif" dengan persentase peningkatan dari siklus I ke siklus II sebesar 49,31\%.

Berdasarkan analisis data prestasi belajar siswa dapat disajikan hasil analisis data prestasi belajar siswa seperti pada tabel 02 di bawah ini

Tabel 02. Rekapitulasi Hasil Analisis Data Prestasi Belajar Siswa

\begin{tabular}{|c|c|c|c|}
\hline \multirow{2}{*}{$\begin{array}{c}\text { Indika } \\
\text { tor } \\
\text { Presta } \\
\text { si }\end{array}$} & \multicolumn{2}{|c|}{$\begin{array}{c}\text { Hasil Analisis } \\
\text { Data }\end{array}$} & $\begin{array}{c}\text { Present } \\
\text { ase } \\
\text { Peningk } \\
\text { atan } \\
\text { I }\end{array}$ \\
\hline $\bar{X}$ & $\begin{array}{c}\text { Siklus } \\
\text { II } \\
\text { Siklus } \\
\text { I-II }\end{array}$ \\
\hline KB & $\begin{array}{c}76,82 \\
60,97 \\
\%\end{array}$ & $\begin{array}{c}83,21 \\
\%\end{array}$ & $8,31 \%$ \\
\hline DS & $\begin{array}{c}76,82 \\
\%\end{array}$ & $\begin{array}{c}83,21 \\
\%\end{array}$ & $8,31 \%$ \\
\hline
\end{tabular}

Keterangan:

$\overline{\mathrm{X}}$ : Rata-rata prestasi belajar siswa KB : Ketuntasan Belajar

DS : Daya Serap

Berdasarkan analisis data keterlaksanaan pembelajaran maka dapat disajikan rekapitulasi hasil analisis data keterlaksanaan pembelajaran seperti pada tabel 03 berikut.

\section{Tabel 03. Rekapituasi Hasil Analisis} Data Keterlaksanaan Pembelajaran

\begin{tabular}{|c|c|c|c|}
\hline \multirow{2}{*}{$\begin{array}{c}\text { Sikl } \\
\text { us }\end{array}$} & $\begin{array}{c}\text { Pertem } \\
\text { uan } \\
\text { Ke- }\end{array}$ & $\begin{array}{c}\text { Presentasi } \\
\text { Keterlaksa } \\
\text { naan } \\
\text { Pembelajar } \\
\text { an }\end{array}$ & $\begin{array}{c}\text { Predi } \\
\text { kat }\end{array}$ \\
\hline \multirow{2}{*}{ I } & 1 & $100 \%$ & Baik \\
\cline { 2 - 4 } & 2 & $100 \%$ & Baik \\
\hline
\end{tabular}

\begin{tabular}{|c|c|c|c|}
\hline $\begin{array}{c}\text { Sikl } \\
\text { us }\end{array}$ & $\begin{array}{c}\text { Pertem } \\
\text { uan } \\
\text { Ke- }\end{array}$ & $\begin{array}{c}\text { Presentasi } \\
\text { Keterlaksa } \\
\text { naan } \\
\text { Pembelajar } \\
\text { an }\end{array}$ & $\begin{array}{c}\text { Predi } \\
\text { kat }\end{array}$ \\
\hline \multirow{4}{*}{} & $\begin{array}{c}\text { Rata- } \\
\text { rata }\end{array}$ & $100 \%$ & Baik \\
\cline { 2 - 4 } II & 1 & $100 \%$ & Baik \\
\cline { 2 - 4 } & $\begin{array}{c}\text { Rata- } \\
\text { rata }\end{array}$ & $100 \%$ & Baik \\
\hline
\end{tabular}

\section{Pembahasan}

Berdasarkan hasil observasi awal di kelas XI SMK Saraswati 2 Denpasar Tahun Pelajaran 2014/2015 diperoleh informasi tentang prestasi belajar siswa pada pelajaran matematika belum mencapai hasil yang optimal. Hal ini dapat diketahui dari hasil wawancara dengan guru yang mengajar yang menunjukkan prestasi belajar siswa belum memenuhi kriteria ketuntasan minimum (KKM) yang ditetapkan di SMK Saraswati 2 Denpasar, yaitu: rata-rata nilai prestasi belajar $(\overline{\mathrm{X}}) \geq 78$, ketuntasan belajar $(\mathrm{KB}) \geq 80 \%$, dan daya serap (DS) $\geq$ 78\%. Melihat hal tersebut, maka dilakukan pengamatan terhadap proses pembelajaran matematika. Dari hasil pengamatan terlihat bahwa penyebab utama siswa kesulitan mencapai KKM adalah siswa kurang siap dan terlibat dalam pembelajaran.

Untuk mengatasi permasalahan ini, maka dilakukan penelitian tindakan 
kelas dengan judul "Penerapan Model Pembelajaran Tipe NHT Sebagai Upaya Dalam Meningkatkan Aktivitas Dan Prestasi Belajar Siswa Dalam Pembelajaran Integral Tak Tentu Fungsi Aljbar Pada Siswa Kelas XI SMK Saraswati 2 Denpasar Tahun Pelajaran 2014 / 2015.”

Melalui penerapan pembelajaran kooperatif tipe NHT yang dilaksanakan pada siklus I, diperoleh rata-rata skor aktivitas belajar siswa pada siklus I sebesar 9,43 dengan kategori cukup aktif. Memperhatikan kriteria aktivitas belajar siswa pada Bab III, aktivitas belajar siswa pada siklus I belum optimal sebab belum mencapai kriteria minimal yang ditetapkan yaitu kategori aktif. Berdasarkan hasil observasi aktivitas siswa, pelaksanaan pembelajaran pada siklus I belum optimal dikarenakan: (1) Beberapa siswa tampak ribut saat penjelasan materi, (2) Beberapa siswa kurang aktif dalam kelompoknya, dan (3) siswa yang memilik kemampuan kurang terlihat malu untuk bertanya apabila mengalami kesulitan, (4) siswa yang lebih pintar dapat mengerjakan sendiri tugas yang diberikan tanpa membantu anggota kelompoknya yang mengalami kesulitan.

Hasil analisis data prestasi belajar siswa pada siklus I diperoleh rata-rata nilai prestasi belajar siswa sebesar 76,82 $(\overline{\mathrm{X}})$,Ketuntasan Belajar (KB) sebesar $60,97 \%$, dan daya serap (DS) sebesar 76,82\%. Apabila dilihat dari kriteria ketuntasan minimal yang ditetapkan di SMK Saraswati 2 Denpasar, maka rata-rata prestasi belajar siswa, ketuntasan belajar, dan daya serap siswa belum memenuhi kriteria ketuntasan minimal yang ditetapkan yaitu: rata-rata nilai prestasi belajar siswa $(\overline{\mathrm{X}}) \geq 78$, Ketuntasan Belajar $(\mathrm{KB}) \geq 80 \%$, dan Daya Serap (DS) $\geq 78 \%$.

$$
\text { Hasil analisis data }
$$

keterlaksanaan pembelajaran pada siklus I diperoleh rata-rata persentase keterlaksanaan pembelajaran yaitu sebesar $100 \%$ dengan kategori sangat baik. Memperhatikan kriteria keterlaksanaan pembelajaran siswa pada Bab III, keterlaksanaan pembelajaran pada siklus I sudah optimal sebab sudah mencapai kriteria minimal yang ditetapkan yaitu kategori baik, namun lebih ditekankan pada penelitian ini adalah aktivitas belajar siswa dan prestasi belajar siswa, 
sehingga penelitian tetap dilanjutkan pada siklus II.

Berdasarkan perbaikan tindakan yang dilakukan pada siklus II diperoleh rata-rata skor aktivitas belajar siswa yaitu sebesar: 14,08 dengan kategori aktif. Jika dibandingkan dengan hasil analisis data skor aktivitas belajar siswa pada siklus I, nampak terjadi peningkatan aktivitas belajar siswa dari siklus I ke siklus II. Pada siklus I aktivitas belajar siswa berada pada kategori cukup aktif, menjadi aktif pada siklus II. Dari hasil analisis data prestasi belajar siswa pada siklus II diperoleh rata-rata nilai prestasi belajar siswa $(\overline{\mathrm{X}})$ sebesar 83,21 , Ketuntasan Belajar (KB) sebesar $80,48 \%$ dan daya serap (DS) sebesar $83,21 \%$. Bila dibandingkan dengan siklus I, maka pada siklus II menunjukkan peningkatan prestasi belajar siswa dengan persentase peningkatan rata-rata nilai prestasi belajar $(\overline{\mathrm{X}})$ sebesar: $8,31 \%$, persentase peningkatan Ketuntasan Belajar (KB) sebesar: $31,99 \%$, dan persentase peningkatan Daya Serap (DS) sebesar: $8,31 \%$. Hasil analisis data keterlaksanaan pembelajaran pada siklus II, Berdasarkan hasil analisis data keterlaksanaan pembelajaran pada siklus II, rata-rata presentase keterlaksanaan pembelajaran mencapai 85\% dengan kategori baik.

\section{PENUTUP}

\section{Simpulan}

Berdasarkan hasil penelitian dan pembahasan, maka dapat disimpulkan sebagai berikut:

1. Aktivitas belajar siswa dalam pembelajaran integral tak tentu fungsi aljabar melalui penerapan pembelajaran kooperatif tipe NHT pada siswa kelas XI SMK Saraswati 2 Denpasar tahun pelajaran 2014/2015 mengalami peningkatan, yaitu dari kategori "cukup aktif" pada siklus I, meningkat menjadi “aktif" pada siklus II, dengan persentase peningkatan dari siklus I ke siklus II sebesar 49,31\%.

2. Peningkatan Prestasi belajar siswa dalam integral tak tentu fungsi aljabar melalui penerapan pembelajaran kooperatif tipe NHT pada siswa kelas XI SMK Saraswati 2 Denpasar ditunjukkan dengan peningkatan rata-rata nilai prestasi belajar siswa $(\overline{\mathrm{X}})$, ketuntasan belajar ( KB), dan daya serap ( DS ) dari siklus I ke siklus II berturut-turut sebesar $8,31 \%$; 31,99\%; dan 8,31\%. 


\section{Saran}

Berdasarkan simpulan tersebut di atas, maka saran yang dapat disampaikan sebagai berikut:

1. Kepada guru matematika di SMK Saraswati 2 Denpasar disarankan agar menerapkan model pembelajaran kooperatif tipe NHT sebagai salah satu alternatif dalam pemilihan model pembelajaran matematika.

2. Kepada pihak sekolah, diharapkan hasil penelitian ini dapat dijadikan sebagai bahan pertimbangan untuk meningkatkan aktivitas dan prestasi peserta didik di sekolah dan juga sebagai bahan pertimbangan dalam penyempurnaan kurikulum sebagai salah satu model pembelajaran yang dapat meningkatkan prestasi belajar siswa.

3. Penelitian ini karena terbatas pada peningkatan aktivitas dan prestasi belajar siswa dalam pembelajaran integral tak tentu fungsi aljabar pada siswa kelas XI SMK Saraswati 2 Denpasar tahun pelajaran 2014/2015, maka peneliti lain yang berminat melakukan penelitian sejenis agar mengadakan penelitian secara lebih mendalam dengan mengambil subjek penelitian dan pokok bahasan yang berbeda dalam upaya meningkatkan aktivitas dan prestasi belajar siswa.

\section{DAFTAR PUSTAKA}

Trianto, 2008. Model-model Pembelajaran Inovatif Berorientasi Kontrutivisik. Surabaya: Prestasi Pustaka.

Hopkins, 2011. Penelitian Tindakan Kelas, (Online) Model Kemmis dan Mc Taggart PDF digilib.unila.ac.id

Yanti,Eni Ni Putu. Penerapan Pembelajaran Kooperatif Tipe NHT Sebagai Upaya Meningkatkan Aktivitas dan Prestasi Belajar Siswa Dalam Pembelajaran Segitiga Pada Sisiwa Kelas VIIA SMP Negeri 4 Kediri Tahun Pelajaran 2013/2014. Skripsi tidak diterbitkan, Denpasar. Fakultas Keguruan dan Ilmu Pendidikan Universitas Mahasaraswati Denpasar.

Puspitasari, Ni Kadek Mahardika. 2013. Implementasi Model Quantum Teaching Sebagai Upaya Meningkatkan Aktivitas dan Prestasi Belajar Siswa dalam Pembelajaran Garis dan Sudut pada Siswa Kelas VII I SMP Negeri 1 Kuta Utara. Skripsi (tidak diterbitkan). 